Industrial Health, 1981, 19, 9.

\title{
HISTOPATHOLOGICAL STUDIES WITH REFERENCE TO CHRONIC CADMIUM EXPOSURE IN ADRENAL AND SPLEEN OF COMMON INDIAN GROUND SQUIRREL (FUNAMBULUS PENNANTI, WROUGHTON)
}

\author{
Ramendra Kumar MITHAL, Ph. D. \\ Department of Zoology, D. N. Postgraduate College, Meerut City \\ 250 002, U. P., India
}

(Received September 29, 1980)

\begin{abstract}
Histopathological changes in adrenal and spleen have been observed in squirrels after i.p. injections of cadmium acetate at a daily dose of $1.0 \mathrm{mg}$ $\mathrm{Cd} / \mathrm{Kg}$ of body weight. Adrenals revealed dilatation of sinusoids together with fatty change in the cells of cortex, hyaline-like mass in medulla, haemorrhage just adjacent to medulla, circumscribed haemorrhage in cortex and congested blood vessels after different intervals of exposure time. Whereas, spleen showed congestion in blood vessels alongwith thickness of vessel wall and congestion and dilatation of sinusoids. Final body weight gain of cadmium treated squirrels was significantly $(P<0.05)$ different from the controls. The rise in spleen weight was also significantly higher $(P .<0.05)$.

Key words: Cadmium exposure-Squirrel - Histopathology - Adrenal-Spleen - Body weight
\end{abstract}

\section{INTRODUCTION}

Cadmium is extensively used in industries. This heavy metal in the recent years emerged as an important environmental pollutant. Cadmium was considered as the root cause of an epidemic of bone disorder, itai-itai disease in Japan in the late 1960s.

The author ${ }^{1)}$ has reported lesions of adrenal and spleen after one week of a single cadmium acetate administration in squirrels. The present study describes histopathological alterations in adrenal and spleen of squirrel ( $F$. pennanti, Wroughton) after chronic cadmium acetate exposure.

\section{MATERIALS AND MethodS}

Thirty two laboratory-bred squirrels of both sexes with body weight of $100 \pm 10 \mathrm{~g}$ were kept in steel-wired cages $(60 \times 48 \times 40 \mathrm{cms})$ and allowed to feed on whealt-flour bread and tap water ad libitum. The animals were divided into two equal groups: group-A of 16 squirrels was injected intraperitoneally with a daily dose of cadmium acetate (1.0 


\section{R.K. MITHAL}

$\mathrm{mg} \mathrm{Cd} / \mathrm{Kg}$ of body weight), and group-B of 16 squirrels served as control. The control group received distilled water by the same route. Four squirrels from each of the groups were sacrificed after different intervals, viz. 4, 5, 6 and 7 weeks by decapitation after light ether anesthesia. Adrenals and spleen were removed from the animals of both groups as quickly as possible and weighed. Small pieces (5 $\mathrm{mm}$ in thickness) of spleen were cut and fixed in $10 \%$ formol-saline. Paraffin sections of adrenal and spleen of treated and control groups were cut at 3-4 $\mu$ and stained with haematoxylin-eosin. Body weight of the animals of both groups was recorded weekly.

\section{Results}

Body weight, adrenal and spleen weights in both experimental and control groups of squirrels are given in Fig. 1 and table-1.

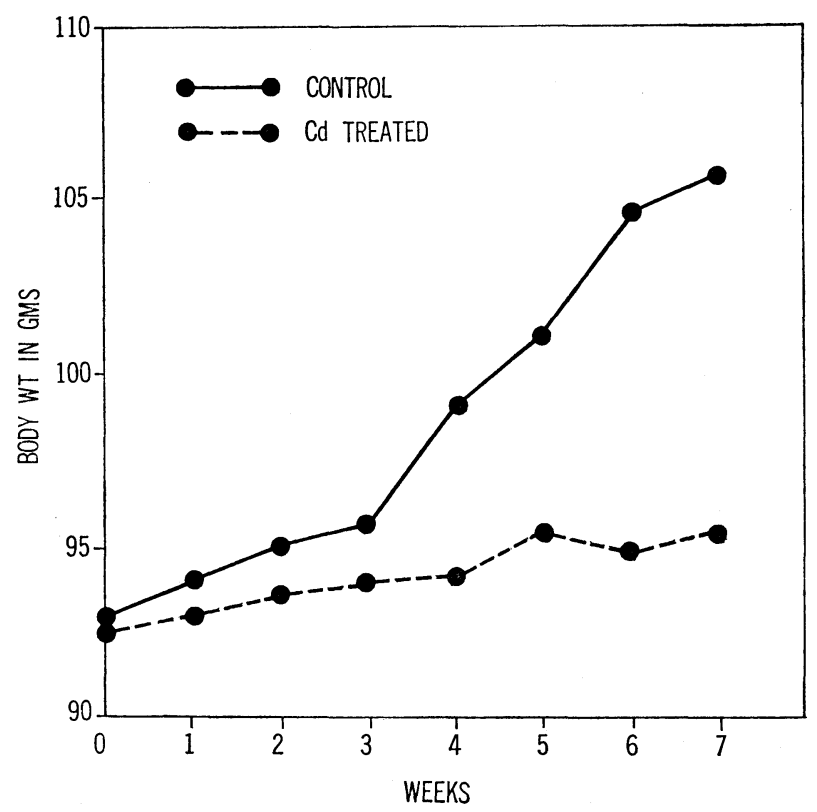

Fig. 1. Effect of cadmium on body weight in squirrels.

Table-1. Effect of cadmium on adrenal and spleen weight in squirrels

\begin{tabular}{ccc}
\hline \multirow{2}{*}{ Groups } & \multicolumn{2}{c}{ Organ Weight $(\mathrm{g})$ after final time } \\
\cline { 2 - 3 } & Adrenal & Spleen \\
\hline Control & $0.036 \pm 0.00836$ & $0.29 \pm 0.063$ \\
Cd Treated & $0.41 \pm 0.00629$ & $0.64^{*} \pm 0.095$ \\
\hline
\end{tabular}

values are expressed in mean

* significantly different from the control $(p<0.05)$

\pm standard error 


\section{EFFECTS OF CADMIUM ON ADRENAL AND SPLEEN}

\section{Adrenal}

Adrenal cortex revealed dilatation of sinusoids together with fatty change in the cells of zona faciculata (Fig. 2); and the medulla appeared to have a granular homogeneous hyaline-like mass after five weeks of cadmium administration. Whereas, after six weeks of cadmium exposure revealed congested blood vessels, haemorrhage just adjacent to the medulla, circumscribed haemorrhage in cortex of a few animals and fatty change in cortical cells, especially in the cells of zona faciculata and hyaline like masses iu medulla. Haemorrhage in the cells of zona reticularis (Fig. 3), congested blood vessels and hyaline like aggregate (Fig. 4) in medullary region were observed after seven weeks of the metal intoxication.

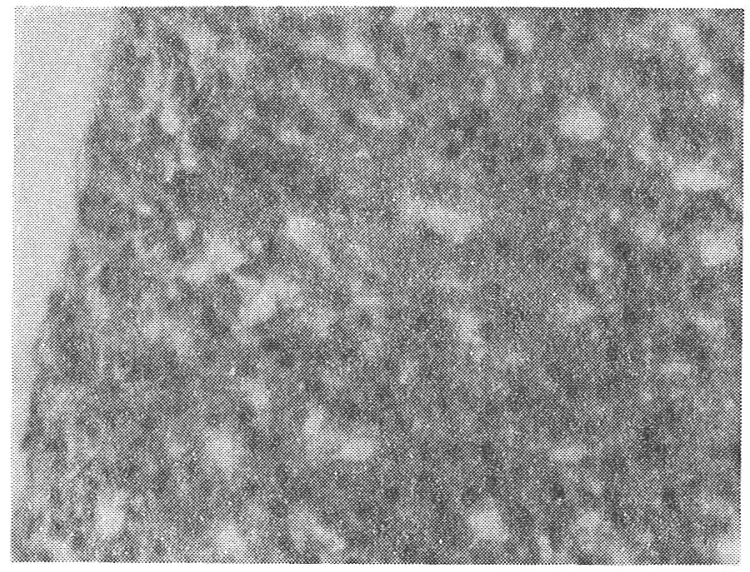

Fig. 2. Cells of zona faciculata reveal mild fatty change after five weeks of chronic cadmium exposure $\times 280$ (original magnification), $\mathrm{H} \& \mathrm{E}$.

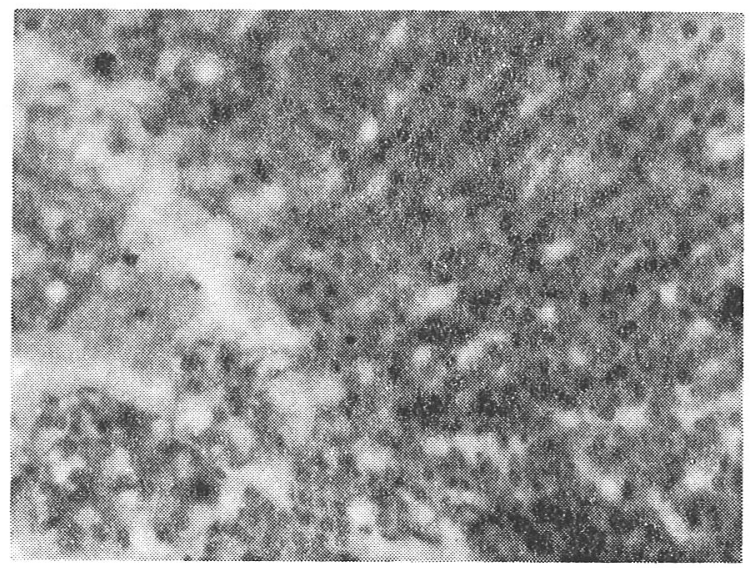

Fig. 3. Congestion in zona reticularis after seven weeks of chronic cadmium exposure. $\times 280$ (original magnification), $\mathrm{H} \& \mathrm{E}$. 


\section{R.K. MITHAL}

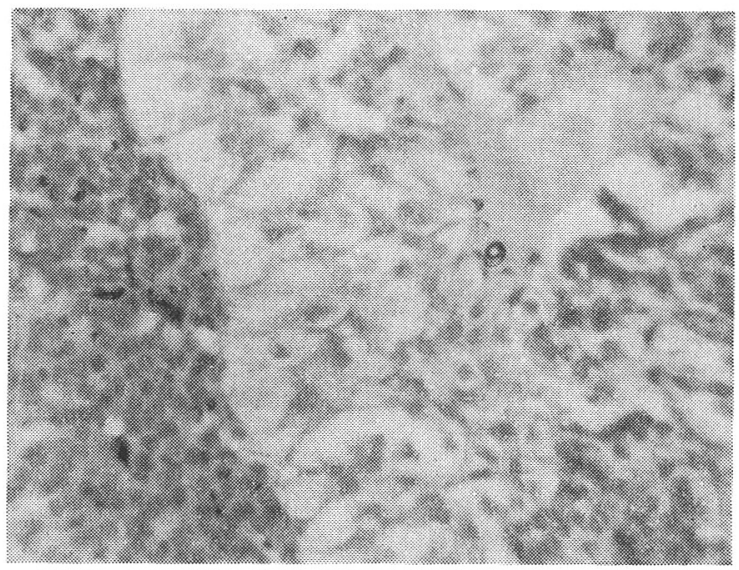

Fig. 4. Congestion and hyaline-like mass in medulla after seven weeks of chronic cadmium exposure. $\times 280$ (original magnification), $\mathrm{H} \& \mathrm{E}$.

\section{Spleen}

Slight congestion in blood vessels alongwith thickness of vessel wall (Fig. 5) were observed after five weeks after cadmium exposure. Whereas, after six weeks congestion and dilatation of sinusoids were noticed together with stuffed blood vessels; congestion in the white pulp (Fig. 6) was well marked. Seven weeks after the metal intoxication, pathological changes were more or less similar to six weeks condition. Besides these changes, the red pulp also revealed congestion during this period.

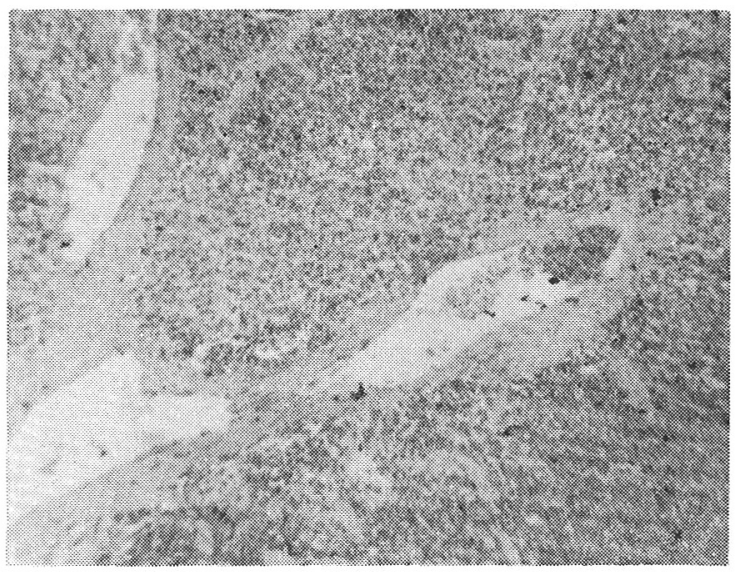

Fig. 5. Congestion in the blood vessel and thickening of its wall after five weeks of chronic cadmium exposure. $\times 70$ (original magnification), $\mathrm{H} \& \mathrm{E}$. 


\section{EFFECTS OF CADMIUM ON ADRENAL AND SPLEEN}

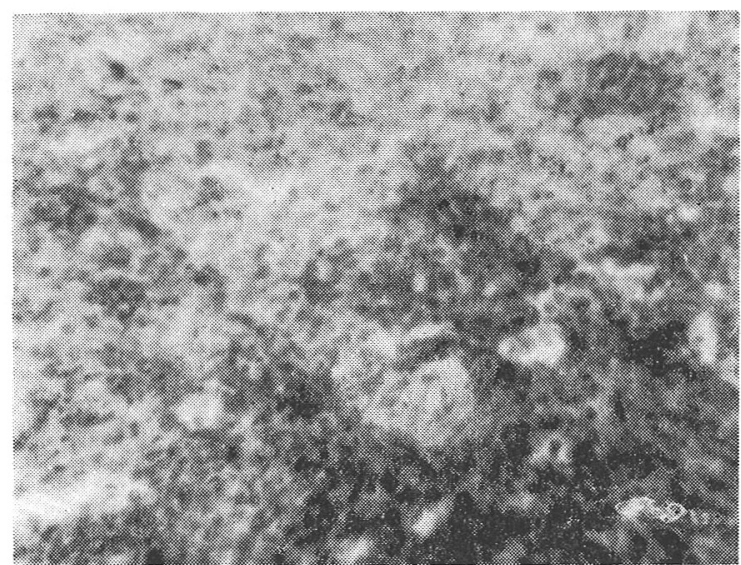

Fig. 6. Congestion and dilatation of sinusoids of red pulp after seven weeks of chronic cadmium exposure. $\times 280$ (original magnification), $\mathrm{H} \& \mathrm{E}$.

\section{Discussion}

Final body weight gain of cadmium treated squirrels was significantly $(\mathrm{P}<0.05)$ different from the controls. Present finding suggests stunted growth rate after chronic exposure of the metal.

Present findings suggested increase in adrenal and spleen weight after chronic exposure of the metal. The rise in spleen weight was significantly higher $(P<0.05)$. Der, et $a l^{2}$ reported similar finding in cadmium exposed albino rats.

Chronic cadmium administration revealed congestion in the blood vessels in adrenals. The haemorrhages were observed in zona reticularis. However, the cortex showed circumscribed haemorrhage in cortex. Adrenal haemorrhage have been described to occur due to toxic action of certain compounds in $\operatorname{man}^{3)}$. The haemorrhage might have appeared due to damaging effect in vessel wall or by the red blood cells escaping by a process of diapedesis. Gabbiani, et $a l^{4)}$ reported that cadmium has degenerative effect on endothelium of blood vessels. The present author suggestes that haemorrhage might have occurred due to this effect of cadmium. Fatty change was generalized in the cortex after 6 weeks, whereas, it was restricted to zona faciculata after 5 weeks. The cortical cells contain abundant lipid globules in the cytoplasm in masked form. The unmasking of lipid might have revealed fatty change, a change which has been mentioned by the present author in liver after chronic cadmium administration in squirrels ${ }^{5}$. The hyaline like aggregates were also noticed in medulla. Hyalinization is one of the commonest degenerations and most obscure. It represents an end stage of many degenerative processes. It is referred to correspond with coagulation of protein; and it is therefore suggested that it might have resulted in hyalinization of some of the cells of medulla because cadmium has been reported to bind with the proteinous material of the cells ${ }^{6,7}$. 


\section{R.K. MITHAL}

Chronic cadmium exposure revealed congestion and dilatation of sinusoids after 6 and 7 weeks. The blood vessels were found to be congested after different intervals. In human beings, the venous congestion may be systemic in origin, it might have been caused by intrahepatic obstruction to portal venous drainage, or may be due to obstructive venous disorders in the portal or splenic veins ${ }^{3)}$. Der, et al ${ }^{8)}$ reported splenomegaly in cadmium fed rats. These authors described that the histology of spleen showed sequestration of numerous red blood cells in red pulp. The present author did not observe this change in spleen, however, there appeared congestion in the pulp.

\section{ReFERENCES}

1) Mithal, R. K. (1979). Influence of short-term cadmium exposure in lung, adrenal and spleen of common Indian ground squirrel after different administrative routes. Annot. Zool. Japon., Tokyo, Communicated.

2) Der, R., Fahim, Z., Yousef, M. and Fahim, M. (1976). Res. Commun. Chem. Pathol. Pharmacol., 14, 689.

3) Robbins, S. L. (1966). Text book of Pathology with Clinical Applications. II Ed., W. B. Saunders Company, Philadelphia, p. 529.

4) Gabbiani, G., Banonnel, M., Mathewson, S. M. and Ryan, G. B. (1974). Lab. Invest, 30, 686.

5) Mithal, R. K. (1980). Hepatic lesions in experimental chronic cadmium poisoning of common Indian ground squirrel (Funambulus pennanti, Wroughton): Histopathological and enzymological studies. Jap. J. Exp. Med., Tokyo, Communicated.

6) Nordberg, G. F. (1972). Environ. Physiol. Biochem., 2, 7.

7) Nordberg, M. and Nordberg, G. (1973). Abstracts of IXth International Congress on Biochemistry, Stockholm. p. 82.

8) Der, R., Yousef, M., Fahim, Z. and Fahirn, M. (1977). Res. Commun. Chem. Pathol. Pharmacot., 17, 237. 